Jurnal Tarbawi| Volume 2|No 1| ISSN 2527-4082| 12

\title{
KOHESIVITAS BUDAYA SIRI' MASYARAKAT PESISIR KOTA MAKASSAR DALAM PERSPEKTIF HUKUM ISLAM DAN PENDIDIKAN
}

\author{
Ahmad Nashir ${ }^{1}$ \\ ${ }^{* 1}$ Pendidikan Agama Islam Fakultas Agama Islam| Unismuh Makassar \\ Ahmadnashir54@gmail.com
}

\begin{abstract}
ABSTRAK
Penelitian ini bertujuan untuk mengetahui kohesivitas budaya siri' masyarakat pesisir Kota Makassar dalam perspektif hukum Islam dan pendidikan. Penelitian ini bersifat kualitatif deskriptif. Untuk melengkapi data penelitian digunakan instrumen penelitian observasi, wawancara, dokumentasi, sehingga data terkumpul dan dianalisis. Hasil penelitian menunjukkan bahwa, dalam ajaran Islam, siri' sangat dijunjung tinggi dan dijaga karena siri atau malu adalah bagian dari iman. Masyarakat Makassar terutama dalam masyakat Tanjung Bunga Kota Makassar, budaya Siri Makassar masih dipertahankan dari generasi ke generasi dan masih diterapkan dalam masyarakat, tapi secara umum budaya siri Makassar mulai bergeser dengan pengaruh budaya modernisasi dan globalisasi serta perkembangan dan kemajuan teknologi yang semakin pesat dan merubah perilaku masyarakat sedikit demi sedikit. Ditinjau hukum Islam, dalam mempertahankan lima aspek dalam syariat baik dalam hal agama merupakan perhatian yang sangat besar dalam keluarga, dan masyakat sehingga dalam proses pernikahan dalam konteks masyarakat Makassar dalam proses pelamaran dalam pernikahan, salah satu item pertanyaan adalah pemahamannya terhadap agama. Ditinjau dari pendidikan, disiplin adalah harkat, martabat dan harga diri yang merupakan refleksi dari ketinggian siri'.
\end{abstract}

Kata Kunci: Budaya Siri, Hukum Islam dan Pendidikan

\begin{abstract}
This study aims to determine the cultural cohesiveness of siri 'coastal community of Makassar City in the perspective of Islamic law and education. This research is qualitative descriptive. To complement the research data used observation research instruments, interviews, documentation, so the data collected and analyzed. The results show that, in Islamic teachings, siri 'is highly esteemed and guarded because siri' or shame is part of the faith. Makassar society, especially in the community of Tanjung Bunga Makassar city, Makassar Siri" culture is still maintained from generation to generation and still applied in society, but generally Makassar siri' culture began to shift with the influence of modernization culture and globalization and the rapid development and technological progress and change the behavior Community little by little. In terms of Islamic law, in maintaining the five aspects of the Shari 'a in terms of religion is a very big concern in the family, and the community so that in the process of marriage in the context of Makassar society in the process of marriage in the marriage, one of the question items is his understanding of religion. Judging from education, discipline is the dignity, dignity and selfesteem which is a reflection of siri' height'.
\end{abstract}

\section{Keywords: Siri Culture, Islamic Law and Education}




\section{PENDAHULUAN}

Relasi budaya dan sosial dalam
suatu masyarakat yang sedang mengalami perkembangan pembangunan telah menjadi suatu keniscayaan tersendiri, maka perkembanagn pembangunan itu menjadi wujud terhadap kemajuan budaya sosial suatu daerah ataupun kota. Budaya masyarakat dapat menjadi hukum yang mengikat suatu masyarakat, maka secara sederhana budaya dapat diterapkan bila ditunjang struktur hukum yang berkaitan dengan tatanan kelembagaan dan kinerja kelembagaan beserta dengan aparatnya dalam melaksanakan dan menegakkan hukum, termasuk di dalamnya pola bagaimana hukum itu dilaksanakan dan ditegakkan sesuai dengan aturan formalnya Lawrence M. Friedman, (1984: 5 )

Ramalan seorang Alvin Toffler, bahwa akan suatu arus globalisasi akan berefek pada paradox mendorong terhadap kuatnya semangat untuk menonjolkan karakter lokalitas. Fenomena tersebut tentu memiliki nilai positif value positive, hal itu sangat terkait secara strategis bila dikaitkan dengan kebijakan pemerintah mengenai otonomi daerah yang memberi ruang kepada daerah untuk mengembangkan diri seluas mungkin. Secara lokalita, pemerintah Kota Makassar sedang membuat program dengan tagline: "Makassar menuju Kota Dunia". Secara sederhana bahwa sebagian kemajuan dunia dipelopori dipelopori oleh masyarakat Makassar.Namun demikian, dapat berdampak pada era otonomi daerah yang seluas-luasnya juga berdampak negatif bagi lokalitas potensi disintegrasi dari Negara Kesatuan Republik Indonesia.

Lokasi pesisir yang terpencil juga merupakan nilai jual yang tinggi dari sudutpandang pariwisata konvensional. Investor telah memanfaatkan peluang ini untukmerubah keterpencilan pesisir menjadi objek wisata yang menawan dan ekslusif, yang diperuntukkan bagi wisatawan yang ingin sekejap mengasingkan diri dari hiruk-pikuk keseharian dan menikmati keeksotisan pantai yang indah dan bersih.

Dampak positif hanya diperoleh bagi mereka telah menyiapkan diri dan komunitasnya untuk menjemput perubahan-perubahan itu.Tentu bila suatu masyarakat dapat berinteraksi dengan dinamis dengan perubahan maka patut diduga bahwa masyarakat tersebut memiliki kesiapan mental yang ditandai dengan konsistensi masyarakat memengang falsafah hidupnya yang terlahit dari nilai-nilai kearifan lokal. Sementara bagi masyarakat pesisir akan menerima dampak negatif kemajuan tersebut, sebab mereka belum siap secara fisik dan nonfisik. Artinya kualitas sumber daya manusia (SDM) baik mental maupun kemampuan ekonomi. Maka kedua hal tersebut terakumulasi pada pergeseran budaya lokal dan menerima budaya luar secara mentahmental yang tentu tidak dapat dijamin 
dapat merusak hubungan kohesivitas budaya siri' diantara sesama masyarakat pesisir.

Dalam konteks hukum Islam, budaya masyarakat yang baik dapat menjadi hukum dan dapat diterapkan dalam masyarakat sebagai perekat, spirit dan kehormatan dalam interaksi masyarakat baik secara internal maupun dengan eksternal dengan budaya luar artinya: adat merupakan hukum, bila dipahami secara filosofis maka adat-adat yang baik dan hidup masyarakat dapat dipedomani untuk menjadi perekat, spirit maupun regulator bagi masyarakat. Tentu budaya siri' bagi masyarakat pesisir kota Makassar telah ada dan dipraktekkan dalam secara turun temurun, dalam kata yang abstrak dimanifestasikan diatas kehormatan dan keinginan untuk dihormati. Hal itulah menjadi kepercayaan diri bagi masyarakat bahwa eksistensi budaya siri' telah berkonstribusi positif dalam mendorong kemajuan pembangunan Kota Makassar.

Pasca disahkannya Keputusan Menteri Kelautan dan Perikanan Nomor 18 Tahun 2004 Tentang Pedoman Umum Pelaksanaan Pemberdayaan Ekonomi Masyarakat Pesisir (PEMP) telah membawa harapan perubahan bagi pengembangan kawasan pesisir dengan berbasis pemberdayaan masyarakat.

\section{METODE PENELITIAN}

Metode yang digunakan dalam penelitian ini adalah metode kualitatif deskriptif. Penelitian deskriptif merupakan penelitian yang bertujuan menggambarkan suatu kondisi atau fenomena sosial dan hukum, tidak memilah-milah atau mencari faktorfaktor atau variabel tertentu. Desain penelitian deskriptif ini umumnya dapat menggunakan metode studi kasus, tindak lanjut, analisis konten, serta kecenderungan termasuk kemungkinan ada korelasional masalah dengan sosial dan hukum.

Penelitian kualitatif tidak mengenal istilah populasi melainkan menggunakan istilah "situasi sosial" (social situation) yang memiliki tiga elemen, yaitu tempat (place), pelaku (actors), serta aktivitas (activity) yang berinteraksi secara sinergis dan tidak dapat dipisahkan (Sugiyono, 2009). Teknik yang digunakan dalam penelitian ini ada tiga macam, yaitu:

1. Studi Kepustakaan

Pengumpulan data pertama-tama dilakukan melalui pengkajian literatur untuk mengungkapkan teori-teori yang relevan dengan topik penelitian

\section{Wawancara}

Wawancara yang dimaksud adalah Wawancara dengan model percakapan kedua belah pihak. Dalam konteks penelitian ini, peneliti merupakan pewawancara dengan mewawancarai para pihak yang dianggap memiliki keterkaitan dengan penelitian ini, yakni; Pemerintah, tokoh 
masyarakat, masyarakat biasa, yang tinggal di pesisir Pantai Tanjung Bunga.

\section{Observasi}

Observasi menjadi suatu kemutlakan untuk melakukan pengamatan, pencatatan dan perekaman secara sistematis mengenai suatu peristiwa baik berupa gejala, perilakuperilaku informan yang terjadi dalam suatu peristiwa dan situasi tertentu, bukan seperti yang mereka ingat, diceritakan kembali, dan digeneralisasikan oleh partisipan itu sendiri (Daymon dan Holloway, 2008).

\section{HASIL PENELITIAN DAN PEMBAHASAN}

\section{A. Kohesivitas Budaya Siri Masyarakat Pesisir Tanjung Bunga Kota Makassar dalam Perspektif Hukum Islam}

Dari aspek ontologi (wujud) siri' na pacce mempunyai relevansi kuat dengan pandangan Islam dalam kerangka spiritualitas, dimana kekuatan jiwa dapat teraktualisasi melalui penaklukan jiwa atas tubuh. Sedemikian rupa, siri' na pacce merupakan emanasi dari Islam yang berbusana bugismakassar yang lahir dari rahim akulturasi Islam dan bugis-makassar.

Inti budaya siri' na pacce itu bukan cuma berkaitan pernikahan. Tapi, mencakup seluruh aspek kehidupan orang Bugis-Makassar. Karena, siri’ na pacce itu merupakan jati diri bagi orang
Bugis-Makassar," Dengan adanya falsafah dan ideologi Siri' na pacce , maka keterikatan dan kesetiakawanan di antara mereka mejadi kuat, baik sesama suku maupun dengan suku yang lain. Konsep Siri' na Pacce bukan hanya di kenal oleh kedua suku ini, tetapi juga suku-suku lain yang menghuni daratan Sulawesi, seperti Mandar dan Tator. Hanya saja kosakatanya yang berbeda, tapi ideologi dan falsafahnya memiliki kesamaan dalam berinteraksi.

Berdasarkan hasil wawancara dengan warga Tanjung Bunga atas nama Daeng Tarru mengatakan bahwa budaya Siri Makassar masih dipertahan dari generasi ke generasi termasuk dia mengatakan penerapannya kepada anakanaknya. Dia juga mengatakan bahwa budaya siri ini perlu lebih diperhatikan dan dijaga karena erat kaitannya dengan harga diri masyarakat Makassar.

Sedangkan menurut Pak Syamsuddin mengatakan bahwa budaya siri Makassar masih dipertahankan sekalipun seraca umum masyarakat sudah mulai ada yang meninggalkan karena pengaruh media dan modernisasi, terutama dikalangan anak muda, tetapi sebagai orang tua selalu mengingatkan tentang bagaimana harga diri yang harus dijaga dalam menjalani sebagai harga diri orang Makassar dan terus harus di lestarikan dan dipertahankan kehidupan sehari-hari.

Ibu Fatimah Nuhung mengatakan bahwa budaya siri konsep masih tetap dipertahankan, tetapi secara aplikasi sudah mulai bergeser dengan majunya 
teknologi seperti; televisi, handpone dan internet, inilah yang banyak merobah perilaku anak-anak masa kini yang sudah mulai meninggalkan budaya siri dan sudah mulai berinteraksi dengan masyarakat secara luas.

Sedangkan menurut Daeng Tutu mengatakan bahwa budaya masih dipertahankan sekalipun pergeseran budaya siri sudah mulai terasa dan terlihat dalam kehidupan sehari-hari, Tapi salah satu upaya dan cara untuk mempertahankan budaya dan adat yaitu dengan adanya festival budaya setiap tahun, termasuk bagaimana mempertahankan budaya siri itu sendiri.

Ada beberapa penyebab timbulnya siri', misalnya: apabila ada seorang pria dan wanita yang menikah tanpa persetujuan keluarga mempelai wanita (kawin lari), maka hal tersebut dianggap siri' (memalukan/merusak harga diri keluarga); apabila ada orang yang ditampar di depan umum, maka hal tersebut termasuk siri' (dipermalukan); apabila ada seorang yang pergi merantau untuk memperbaiki kehidupannya, maka dia merasakan malu (siri') apabila harus pulang tanpa hasil (gagal); apabila ada orang yang melanggar aturan agama (berzina), maka orang tersebut telah melanggar siri' (berbuat hal yang memalukan), dan masih banyak contoh lainnya.

Dalam ajaran Islam, siri' sangat dijunjung tinggi karena apabila kita mempertahankan harga diri dengan alasan yang jelas dan merasakan malu bila akan melakukan perbuatan yang salah maka hal tersebut sangat dibenarkan. Apabila seseorang sudah tidak memiliki lagi perasaan malu untuk berbuat apa saja maka segala perbuatan yang melanggar aturan-aturan agama, adat, hukum dan norma-norma yang lain akan dilakukannya tanpa beban apapun.

Oleh sebab itu, maka perlu dijelaskan tentang maksud dan tujuan siri' na pacce agar dapat memperbaiki pemahaman yang agak menyimpang dari makna dan tujuan sebenarnya. Di samping itu perlu adanya penyelarasan terhadap ajaran Islam, sebab mayoritas masyarakat Makassar khususnya di Tanjung Bayang yang penduduk asli Makassar yang dimekarkan menjadi Tanjung Bunga, pada umumnya masyarakatnya beragama Islam. Dalam kehidupan dan bertingkah laku seharihari menggambarkan budaya Makassar dan sekaligus bernuansa Islami.

\section{Penerapan budaya-budaya siri Makassar di tengah arus modernisasi}

Penetrasi besar-besaran budaya global melalui jalur globalisasi telah membawa banyak perubahan di seluruh penjuru dunia. Ditambah lagi dengan besarnya pengaruh kekuatan ekonomi (economic power) negara-negara maju. Hal ini menempatkan negara berkembang termasuk Indonesia pada posisi yang serba sulit untuk menghindarinya. Satu-satunya jalan adalah mengantisipasinya. Indonesia harus bisa meminimalisir efek negatif yang ditimbulkan dari globalisasi. 
Untuk mewujudkan hal tersebut, dibutuhkan sosok-sosok muda yang memiliki jiwa dan karakter yang mapan. Anak muda Indonesia yang notabene adalah pemimpin dan pemilik masa depan bangsa ini seharusnya memiliki siri' na pacce dalam diri mereka. Karena, anak muda Indonesia yang sudah dijelaskan di awal, adalah anak muda yang sudah terlalu jauh dari akar budaya mereka. Mereka sudah terlalu dalam terkontaminasi oleh pengaruh negatif globalisasi. Dengan adanya siri' na pacce, anak muda akan lebih peka merasakan segala macam persoalan yang sedang melanda Indonesia. Mereka juga akan malu melihat keadaan negaranya serta malu jika ia hanya berdiam diri dan tidak berbuat apa-apa untuk bangsanya.

Pemimpin yang memiliki siri'na pacce dalam dirinya, akan memiliki keberanian serta ketegasan, namun tetap bijaksana dalam memimpin. Pemimpin yang memegang teguh prinsip ini akan membawa perubahan ke arah yang lebih baik karena mereka memiliki rasa peka terhadap lingkungan sekitar. Mereka dapat mendengarkan aspirasi orangorang yang mereka pimpin. Hal ini sangat sejalan dengan konsep negara kita yaitu negara demokrasi.

Meskipun etos siri' na pacce berasal dari masyarakat BugisMakassar, namun etos ini sangat bisa diterima secara nasional. Karena di berbagai daerah Indonesia juga terdapat etos atau pandangan hidup yang hampir sama dengan konsep siri' na pacce. Ada wirang yang hidup di masyarakat suku Jawa, carok pada masyarakat suku Madura, pantang pada masyarakat suku di Sumatera Barat, serta jenga pada masyarakat suku di pulau Bali. Kesemua pandangan hidup dari berbagai daerah tersebut memiliki kesamaan konsep dengan siri' na pacce, yaitu malu jika keadaan suku atau bangsa mereka tidak lebih baik dari suku atau bangsa lain. Kesemua konsep pandangan hidup tersebut menanamkan nilai-nilai luhur tentang semangat serta keberanian tanpa melupakan rasa lembut hati sebagai penyeimbangnya.

Budaya siri Makassar secara umumdi tengah-tengah masyarakat sudah mulai bergeser, sekalipun menurut deng Tarru dalam konteks keluarga masih sangat kental dan itu diterapkan dalam keluarganya.

Lanjut Deng Tarru mengatakan bahwa arus modernisasi sudah mulai menggeser penduduk asli masyarakat Tanjung, terkhusus warga tanjung bumga yang tinggal Sembilan belas kepala keluarga asli, dan tidak menutup kemungkinan akan bergeser atau akan pindah satu persatu dengan adanya perumahan dan pihakpengembang usaha yang semakin meningkat. Selanjutnya perilaku atau anak-anak muda secara umum mulai tidak lagi bergeser dengan majunya teknologi termasuk alat transfortasi, misalnya motor dan anak muda mulai tidak malu lagi berboncengan dengan laki-laki temannya yang bukan muhrimnya bahkan banyak anak muda sekarang pulang ke rumahnya larut malam bersama dengan 
seorang laki-laki ini menandakan bahwa ada pergeseran budaya karena kemajuan teknologi dan arus globalisasi yang tak terbendung lagi sampai hari ini dan masa yang akan datang.

Menurut Daeng Syamsuddin mengatakatan bahwa sebagian masyakarat masih kental dengan budaya siri mereka, tapi sebagian masyarakat sudah mulai berubah perlakunya dan interaksi mereka di tengah tengah perkembangan teknologi dan informasi yang sudah maju serta ikut berdampak terhadap kebiasaan dan perilaku masyarakat secara luas.

Sejak ledakan reformasi menjadi fenomena dominan bangsa ini, tiba-tiba saja wacana-wacana klasik kembali menyeruak ke permukaan dan mengambil tempat cukup urgen untuk dijadikan objek kajian.Wacana-wacana klasik tersebut tidak lain adalah konsep siri' itu sendiri beserta unsur-unsur yang menyertainya.Betapa tidak, hal ini jelas menjadi dominan dibicarakan mengingat sekian banyak kasus siri' (Kolusi, Korupsi dan Nepotisme) yang melibatkan tidak sedikit orang Bugis (Sulawesi Selatan) yang secara kultural sangat peka terhadap Persoalanpersoalan yang menyinggung harga diri dan membangkitkan perasaan primordial untuk tidak menyebut arogansi siri' kedaerahan yang telah lama subur dan berakar di Sulawesi Selatan.

Dalam konteks makro Indonesia di luar Sulawesi Selatan sesungguhnya terdapat konsep yang sama menyangkut siri' yang banyak dianut oleh suku-suku tertentu, misalnya seperti yang dikemukakan oleh Widodo Widodarmobahwa “... siri' yang identik dengan perasaan malu terdapat juga pada suku jawa dengan istilah Wirang, pantang untuk orang, jengauntuk orang Bali dan sebagainya.

Jika ditelaah secara mendalam pengaruh yang paling dominan mewarnai masyarakat yang menganut paham siri' seperti di daerah yang disebut terkhusus dalam wilayah Sulawesi Selatan (Bugis-Makassar, Mandar dan Toraja) dapat dirinci sebagaimana berikut:

1. Meningkatkan tingkat kedisiplinan. Disiplin adalah harkat, martabat dan harga diri yang merupakan refleksi dari ketinggian siri'. Menegakkan disiplin baik terhadap orang lain maupun terhadap diri dan keluarga, sesuai dengan fungsi dan peranan yang harus diemban sama dengan menjaga harkat, martabat dan harga diri. Berarti kita telah menunjukkan diri sebagai seorang yang mempunyai siri'. Siri' pada dasarnya tolok ukur tentang harkat dan martabat. Tolok ukur keseimbangan antara hak dan kewajiban, antara tanggung jawab dan kepatuhan.

2. Siri' itulah yang mendorong keberanian dan ketegaran para pemimpin Appeq Banua Kaiyang sebagai wakil rakyat, untuk secara tegas menentang keputusan Daeng Mallariq.Siri' 
itu pulalah yang menyebabkan Appeq.Banua Kaiyang memecat Daeng Riosok, siri' itu pulalah yang menyebabkan semua raja Mandar mendukung Pammarica untuk menolak permintaan Gubernur Belanda.Hal ini pulalah yang mendorong Puang Cadia untuk secara tegas tanpa raguragu merelakan I Kauseng, anak kandungnya menjalani hukuman mati.

Mewujudkan disiplin nasional, sasarannya tentu saja bukan sekedar menimpa ketaatan dan kepatuhan berdasarkan proses conditioning yang bersifat paksaan. Baik paksaan karena kekuatan maupun paksaan karena hukum.Akan tetapi sasaran yang paling ideal adalah menjadikan disiplin menjadi mental blue print. Sehingga pola tingkah laku yang berstandarisasi, sehingga disiplin telah menjelma sebagai suatu unsur budaya yang hidup dan berfungsi, baik dalam wujud fungsi manifest maupun fungsi latent.

\section{Cara Mempertahankan dan Menanamkan Budaya Siri Makassar}

Budaya Bugis Makassar yang harus dijunjung tinggi dan jika diterapkan akan membawa dampak positif yang besar ialah budaya Siri'na Pacce. Siri' na Pacce adalah sebuah harkat, martabat, dan harga diri serta rasa kasihan yang timbul dari dalam hati masyarakat yang ketika melihat penderitaan orang lain. Oleh karena itu, jika seseorang tidak menanamkan budaya Siri' na Pacce sebagai jati dirinya maka orang tersebut dapat dikatakan layaknya binatang yang tidak memiliki kehormatan diri dan prikemanusiaan. Selain itu, jika para generasi muda menanamkan budaya Siri' na Pacce ini maka bukan hanya menimbulkan harkat, martabat, dan harga diri sebagai seorang manusia, akan tetapi juga akan menimbulkan sifat Tawadhu atau rendah hati dan juga jiwa kepemimpinan yang didamba oleh seluruh masyarakat pada diri masingmasing.

\section{Langkah-langkah mempertahankan lima hal dalam syariat}

Dalam mempertahankan lima aspek dalam syariat yaitu agama, akal, harta, keturunan, dan jiwa, siri' merupakan perhatian yang sangat besar dalam keluarga.

Menurut Daeng Tarru mengatakan bahwa dalam rangka mempertahankan agama dalam kehidupan tertutama dalam keluarga, dia mengatakan bahwa dalam proses pelamaran dalam pernikahan, salah satu item pertanyaan adalah agamanya dan apakah dia rajin ke masjid untuk sholat, terutama sholat jum'at, 
termasuk bacaan alqurannnya dan pemahamannya terhadap agama.

\section{B. Kohesivitas Budaya Siri Masyarakat Pesisir Tanjung Bunga Kota Makassar dalam Perspektif Pendidikan}

Dalam hal menjaga akal ini juga menjadi perhatian tetang bagaimana pola pikir masyarakat yang harus selalu sejalan dengan nilai-nilai alQur'an dan hadis. Pererapan budaya siri na pace dalam pendidikan harus tetap dijaga dan harus dipertahan serta dijalankan dalam kehidupan sehari-hari. Menurut Daeng Syamsuddin mengatakan bahwa budaya siri dalam pendidikan masih terapkan kepada anak-anak teruma dalam pendidikan formal di sekolah, rasa malu ketika terlambat memang seharusnya hanya sekedar disampaikan saja tapi betul diterapkan dalam pendidikan karena ini akan meningkatkan kedisiplinan anak dan siapapun yang terlibat dalam pendidikan dalam rangka untuk membangun kesadaran dan kualitas dalam pendidkan.

Pendidikan merupakan salah satu bentuk perwujudan kebudayaan manusia yang dinamis dan sarat perkembangannya. Oleh karena itu, perubahan atau perkembangan pendidikan adalah hal yang seharusnya terjadi sejalan dengan perubahan budaya kehidupan. Perubahan dalam arti perbaikan pendidikan pada semua tingkat perlu terus menerus dilakukan sebagai antisipasi kepentingan masa depan.

Konsep dan tujuan pendidikan yang ideal tersebut sepertinya mengalami kesenjangan dengan kondisi riil dilapangan, oleh karena itu reaktualisasi nilai-nilai pendidikan perlu dilakukan.Reaktualisasi berarti penyegaran dan pembaruan nilai-nilai kehidupan masyarakat dalam hal ini pendidikan. Pendidikan adalah usaha mengubah tingkah laku individu dalam kehidupan pribadinya atau kehidupan kemasyarakatannya dan kehidupan dalam alam sekitarnya melalui proses pendidikan. Perubahan-perubahan itu berlandaskan nilai-nilai kearifan lokal.

Jadi reaktualisasi nilai siri dalam pendidikan berbasis kearifan lokal merupakan suatu hal yang mutlak dilakukan sebagai salah satu upaya penyegaran dan pembaruan nilai-nilai pendidikan di dalam kehidupan umat yang dewasa ini sedang menghadapi berbagai tantangan dalam berbagai dimensi kehidupan : sosial ekonomi, budaya, politik, IPTEK, dan sebagainya.

\section{Nilai Siri dalam Dimensi Pendidikan}

Pada dasarnya, Siri' na pacce adalah dua unsur suku kata yang menjadi filosofi dasar atau the way of life dalam kehidupan seharihari masyarakat Bugis-Makassar. Dua suku kata ini tidak bisa dipisahkan satu sama lain, dan mempunyai hubungan yang sangat mendalam. Jika dipisahkan, 
secara personal masyarakat akan mengalami lost imagine. Hubunganya bisa seperti penyebab dan akibat.

Budaya siri' na pacce ini juga dikenal di wilayah Indonesia lainnya, seperti wirang yang hidup di masyarakat suku Jawa, corak pada masyarakat suku Madura, pantang pada masyarakat suku di Sumatera Barat, serta jenga pada masyarakat suku di pulau Bali. Semua konsep pandangan hidup yang berkembang dari nilai-nilai luhur ini memiliki kebermaknaan yang sama yaitu tentang semangat serta keberanian tanpa melupakan rasa lembut hati sebagai penyeimbangnya. Sehingga bukan hal yang sulit apabila nilai-nilai siri' na pacce dikembangkan dan diterapkan di Indonesia, karena memang paling Indoensia.

Siri' (malu) merupakan sebuah konsep kesadaran hukum dan falsafah hidup dalam masyarakat BugisMakassar yang dianggap sebagai sesuatu yang sangat sakral.Begitu sakralnya kata tersebut, sehingga apabila seseorang merasa kehilangan Siri'nya, maka tak ada lagi artinya dia menempuh kehidupan sebagai manusia. Jika melihat pada terminologi siri' itu sendiri, maka siri' dapat dimaknai sebagai rasa malu yang terurai dalam dimensidimensi harkat dan martabat manusia, rasa dendam yang berupa hal-hal yang berkaitan dengan kerangka pemulihan harga diri bagi yang merasa dipermalukan atau dinjak-injak martabat dan harga dirinya (Andi Moein Mg, 1990). Jadi Siri' merupakan sesuatu yang sangat tabu bagi kedirian masyarakat Bugis-Makassar dalam interaksi dengan orang lain utamanya dalam hal-hal prinsipil.

Dalam konteks pendidikan kontemporer seperti saat ini, hal ini sangat perlu dipahami dengan seksama. Sebab tanpa memahami nilai tersebut dengan baik, mustahil sebuah arena pendidikan yang mencita-citakan memanusiakan manusia dengan kedewasaan akan hanya menjadi sebuah jargon pendidikan tanpa nilai. Begitupun ketika membenturkan nilai ini ke dalam konteks pendidikan Indonesia yang saat ini dalam suasana diskusi yang hangat.Seakan-akan pendidikan hanya menjadi bahan diskusi tanpa ada penguatan nilai kearifan lokal di dalamnya.

\section{KESIMPULAN}

Berdasarkan hasil wawancara dan pembahasan, maka dapat ditarik kesimpulan sebagai berikut:

1. Kohesitas budaya siri dalam tinjauan hukum Islam masih dipertahankan dan masih dijaga ditengah-tengah masyarakat kota Makassar terkhusus warga Tanjung kota Makassar namun secara luas budaya siri Makassar sudah mulai bergeser sedikit demi sedikat dengan pengaruh globalisasi dan modernisasi serta kemajuan dan perkembangan teknologi begitu pesat. Kehadiran teknogi dan transportasi ditengah-tengah 
masyarakat telah merubah pola hidup masyarakat secara luas. Nilainilai budaya siri Makassar harus selalu dijaga dan lestarikan dalam rangka membangun masyarkat yang bermoral dan berkarakter serta berwibawa. Menjaga agama, harta, jiwa, akal dan keturunan merupakan hal yang sangat urgen dalam kehidupan berbangsa dan bernegara.

2. Kohesitas budaya siri dalam pendidikan tercermin pada sikap kedisiplinan. Disiplin adalah harkat, martabat dan harga diri yang merupakan refleksi dari ketinggian siri'. Menegakkan disiplin baik terhadap orang lain maupun terhadap diri dan keluarga, sesuai dengan fungsi dan peranan yang harus diemban sama dengan menjaga harkat, martabat dan harga diri. Berarti kita telah menunjukkan diri sebagai seorang yang mempunyai siri'. Siri' pada dasarnya tolok ukur tentang harkat dan martabat. Tolok ukur keseimbangan antara hak dan kewajiban, antara tanggung jawab dan kepatuhan.

\section{DAFTAR PUSTAKA}

Abu Hamid. (1996).Sistem Nilai Islam dalam Budaya Bugis-Makassar, dalam Aswab Mahasin, et al. (ed.), Ruh Islam dalam Budaya Bangsa, Aneka Budaya Nusantara (Jakarta: Yaysan Festival Istiqlal.
Ahmad Sewang. (2005). Islamisasi Kerajaan Gowa (Abad XVI sampai XVII), ( Jakarta: Yayasan Obor Indonesia.

A.Partanto, Pius dan M. Dahlan Al Barry,1994, "Kamus Ilmiah Populer", Pen. Arkola, Surabaya.

Bangong Suyatno dan Sutinah (ed), Metode penelitian sosial: berbagai alternatif pendekatan, (Cet. V; Jakarta: Kencana Prenada Media Group, 2010)

Baron, R. A,. \& Byrne, D. (2004). Psikologi Sosial. Edisi Kesepuluh Jilid 1. Jakarta: Erlangga.

Departemen Pendidikan Nasional, 2002, "Kamus Besar Bahasa Indonesia" edisi III, Pen. Balai Pustaka, Jakarta

Echols, John M. Dan Hassan Shadily, "Kamus Inggris-Indonesia", Pen. PT. Gramedia Jakarta.

Emzir, 2008. Metodologi Penelitian Pendidikan (Kuantitatif dan Kualitatif). Jakarta: PT Raja Grafindo persada.

Mattulada, Latoa, Suatu Lukisan Analitis terhadap Antropologi Politik Orang Bugis,(Yogyakarta: Gajah Mada University Press, 1985)

Soehartono, I. (2004), Metode Penelitian Sosial: Suatu Teknik Penelitian Bidang Kesejahteraan Sosial dan Ilmu Sosial Lainnya, PT Remaja Rosdakarya, Bandung.

Satria Efendi, M. Zein, Ushul Fiqh, (Cet. V, Jakarta: PT. Prenadamedia Group, 2014) 
Sudira Wahid, Manusia Makassar, (Makassar: Pustaka Refleksi; 2007)

Universitas Islam Negeri Alauddin Makassar, Pedoman Penulisan Tesis dan Disertasi (Makassar: Pascasarjana UIN Alauddin, 2013

Lembaran Negara Keputusan Menteri Kelautan dan Perikanan Nomor 18 Tahun 2004 Tentang Pedoman Umum Pelaksanaan Pemberdayaan Ekonomi Masyarakat Pesisir

Peraturan Menteri Kelautan dan Perikanan Nomor : Per.16/MEN/2008 Tentang Pengelolaan Wilayah Pesisir dan PulauPulau Kecil.

Winarno, Budi. 2002. Teori dan Proses Kebijakan Publik. Yogyakarta : Media Pressindo. 